\title{
ANALISIS EFISIENSI PEMASARAN AGROINDUSTRI KLANTING DI KECAMATAN NEGERI KATON KABUPATEN PESAWARAN
}

\author{
(Marketing Efficiency's Analysis of Klanting Agroindustry at Negeri Katon Subdistrict, Pesawaran Regency) \\ Radot Vernando Siburian, Ktut Murniati, Ani Suryani
}

Jurusan Agribisnis, Fakultas Pertanian, Universitas Lampung, Jl. Prof. Dr. Soemantri Brodjonegoro No.1

Bandar Lampung 35145, Telp. 089631317369, e-mail: radotvernando@yahoo.co.id

\begin{abstract}
This research aims to know how much income of producer of klanting agroindustry, marketing channels, and the efficiency of klanting agroindustry marketing at Karang Rejo Village, Negeri Katon Subdistrict, Pesawaran Regency, and Lampung Province. The research is conducted by a survey method. The total of respondents is 32 producers and 146 merchants. The research data was collected in December 2016 until March 2017 and analyzed by descriptive qualitative and quantitative. The result showed that the amount of klanting agroindustry producers' income was Rp2,018,932.67/month with $R / C 1.38$ on cash and $R p 1,649,645.49$ /month with $R / C 1.29$ on total cost. It meant that the klanting agroindustry was feasible to be run. In addition, there were four kinds of marketing channels on klanting agroindustry at Karang Rejo Village. Marketing system of klanting agroindustry was still not efficient, because the value of elasticity transmission price was less than one.
\end{abstract}

Key words: agroindustry, efficiency, klanting, marketing

\section{PENDAHULUAN}

Pembangunan pertanian pada dasarnya memiliki tujuan untuk meningkatkan produksi dan produktivitas komoditi, meningkatkan pendapatan dan kesejahteraan petani, menumbuhkan sentra produksi tanaman pangan, mengembangkan sistem pasar dan pemasaran produk hasil pertanian serta menunjang kegiatan industri. Kegiatan industri di Indonesia telah berkembang di berbagai usaha, baik industri skala besar, skala kecil dan industri rumah tangga, baik dari sektor pertanian maupun sektor lainnya (Badan Pusat Statistik Provinsi Lampung 2015).

Sektor pertanian di Provinsi Lampung memiliki peranan penting dalam perekonomian di Indonesia. Subsektor pertanian, kehutanan dan perikanan memiliki nilai sumbangsih paling besar dibandingkan subsektor lainnya dalam kurun waktu empat tahun terakhir, sedangkan posisi kedua dan ketiga ditempati industri pengolahan dan perdagangan besar dan eceran. Hal ini menunjukkan bahwa Provinsi Lampung sangat berpotensi untuk meningkatkan sumber daya alam karena memiliki topografi yang cocok di sektor pertanian (BPS Provinsi Lampung 2015).

Kabupaten Pesawaran merupakan salah satu wilayah yang ada di Provinsi Lampung yang memberikan sumbangsih terhadap nilai barang dan jasa yang digunakan seluruh unit kegiatan ekonomi untuk memenuhi kebutuhan konsumsi, investasi dan ekspor di Provinsi Lampung. Nilai PDRB Kabupaten Pesawaran setiap tahunnya mengalami peningkatan bila dibandingkan dengan sektor lainnya. Subsektor pertanian tanaman pangan memiliki nilai sumbangsih paling besar dibandingkan subsektor lainnya dalam kurun waktu 4 tahun terakhir dengan nilai sebesar $\mathrm{Rp}$ 453.869,52 pada tahun 2014 .

Prospek sektor pertanian sangat memberikan dampak yang positif terhadap kesejahteraan umum dari hasil sumber daya alam yang ada dan dapat meningkatkan nilai tambah dari produk pertanian melalui kegiatan industri. Salah satu sektor industri adalah sektor agroindustri. Jumlah pelaku agroindustri atau kerajinan makanan rakyat yang tersebar di setiap kecamatan di Kabupaten Pesawaran sangat banyak, salah satunya Kecamatan Negeri Katon yang berjumlah 117 pelaku agroindustri. Salah satu tanaman bahan baku pertanian yang dijadikan usaha agroindustri adalah ubi kayu (BPS Kabupaten Pesawaran 2015).

Klanting merupakan makanan yang biasanya tidak dapat memenuhi kebutuhan konsumen secara langsung karena lokasi produksi berbeda dengan lokasi konsumen, maka pemasaran diperlukan dalam penyampaian produk dari produsen ke 
konsumen. Dalam proses pemasaran produkproduk pertanian banyak melibatkan lembagalembaga pemasaran dan tergantung dari jenis produk yang dipasarkan. Penelitian ini bertujuan untuk mengetahui besaran pendapatan usaha agroindustri klanting dan saluran dan efisiensi pemasaran agroindustri klanting.

\section{METODELOGI PENELITIAN}

Penentuan lokasi pengambilan data penelitian dilakukan secara sengaja (purposive) yaitu di Kecamatan Negeri Katon Kabupaten Pesawaran. Pemilihan lokasi ini dilakukan dengan pertimbangan bahwa daerah ini merupakan sentra produksi yang memproduksi ubi kayu yang diolah menjadi produk olahan klanting. Penelitian ini dilakukan pada bulan Desember 2016 - Maret 2017 di Kecamatan Negeri Katon.

Responden dalam penelitian adalah pelaku usaha agroindustri klanting yang berjumlah 32 produsen, 5 pedagang pengumpul, 26 pedagang besar dan 113 pedagang pengecer dan konsumen. Metode pengambilan jumlah responden berdasarkan sensus. Data yang digunakan dalam penelitian ini adalah data primer dan data sekunder. Data primer diperoleh melalui teknik wawancara dan pengamatan secara langsung dengan produsen dan pedagang, sedangkan data sekunder diperoleh dari data instansi terkait yang secara tidak langsung terlibat dalam penelitian ini.

Metode analisis kualitatif digunakan untuk menganalisis pendekatan fungsi-fungsi pemasaran yang dilakukan oleh lembaga pemasaran dan digunakan untuk organisasi pasar yang dilihat dari struktur pasar, perilaku pasar, dan keragaan pasar yang terjadi. Metode analisis kuantitatif digunakan untuk menghitung analisis pendapatan, analisis marjin pemasaran, ratio profit margin, pangsa produsen, dan elastisitas transmisi harga (Sarwono 2006).

Analisis pendapatan digunakan untuk mengetahui selisih antara total penerimaan dengan total biaya produksi yang dikeluarkan sebagai tolak ukur bagi keberhasilan dalam berusaha. Secara matematis dapat dirumuskan sebagai berikut (Rahim dan Hastuti 2008) :

$\mathrm{Pd}=\mathrm{TR}-\mathrm{TC}$
Keterangan :

$\mathrm{Pd}=$ Keuntungan usaha agroindustri klanting $\mathrm{Rp} / \mathrm{kg}$

$\mathrm{TR}=$ Total penerimaan usaha agroindustri klanting

$\mathrm{TC}=$ Total biaya usaha agroindustri klanting

Pendekatan fungsi-fungsi pemasaran dianalisis pada tiap tingkat lembaga pemasaran, baik produsen, pedagang pengumpul, pedagangl besar, maupun pedagang pengecer. Fungsi-fingsi pemasaran yang dilakukan oleh lembaga pemasaran terdiri atas tiga fungsi utama (Hasyim 2012), yaitu :

a. Fungsi pertukaran yang memperlancar perpindahan produk duku dari petani ke konsumen melalui pedagang perantara, dan berhubungan langsung dengan fungsi pembelian dan fungsi penjualan.

b. Fungsi fisik terdiri dari fungsi pengangkutan dan penyimpanan yang mengakibatkan kegunaan bentuk, tempat, dan waktu, terdiri dari fungsi pengangkutan ,fungsi pengemasan, fungsi penyimpanan dan ungsi pengolahan.

c. Fungsi fasilitas adalah semua kegiatan yang memperlancar proses pertukaran produk duku Lampung yang terjadi antara produsen dengan konsumen melalui pedagang perantara, terdiri dari beberapa pendekatan fungsi, yaitu pembiayaan, penanggungan risiko, standarisasi dan grading, informasi pasar.

Marjin pemasaran adalah perbedaan harga pada tingkat produsen $(\mathrm{Pf})$ dengan harga di tingkat pengecer (Pr) yang terdiri dari keuntungan dan biaya (Hasyim 2012). Secara matematis marjin pemasaran dirumuskan sebagai :

$\mathrm{mji}=$ Psi-Pbi atau $\mathrm{mji}=\mathrm{bti}+\pi \mathrm{i}$

Untuk total marjin pemasaran adalah:

$\mathrm{Mji}=\sum_{\mathrm{i}=1}^{\mathrm{n}}$ mji atau $\mathrm{Mji}=\operatorname{Pr}-\mathrm{Pf}$

Keterangan:

$\mathrm{Mji}=$ Total marjin pada satu saluran pemasaran

$\mathrm{Mji}=$ Marjin pada lembaga pemasaran tingkat ke-i

Psi = Harga jual pada lembaga pemasaran tingkat ke-i $(\mathrm{i}=1,2,3, \ldots \ldots ., \mathrm{n})$

Pbi = Harga beli pada lembaga pemasaran tingkat ke-i

$\mathrm{Bti}=$ Biaya pemasaran lembaga tingkat ke-i

Пi $=$ Keuntungan lembaga pemasaran tingkat ke-i

$\mathrm{Pf}=$ Harga di tingkat petani (produsen) 
$\operatorname{Pr}=$ Harga di tingkat konsumen

Penyebaran marjin pemasaran dapat dilihat berdasarkan presentase keuntungan terhadap biaya pemasaran (Ratio Profit Margin) pada masing masing lembaga pemasaran, yang dirumuskan sebagai :

$\mathrm{RPM}=\frac{\pi \mathrm{i}}{\mathrm{bti}}$

Keterangan :

Bti = Biaya pemasaran lembaga pemasaran tingkat ke-i

$\Pi i=$ Keuntungan lembaga pemasaran tingkat ke-i

Nilai RPM yang relatif menyebar merata pada berbagai tingkat lembaga perantara pemasaran merupakan cerminan dari sistem pemasaran yang efisien. Jika selisis RPM antara lembaga perantara pemasaran sama dengan nol, maka sistem pemasara tersebut efisien, dan jika selisih RPM antara lembaga perantara pemasaran tidak sama dengan nol, maka sistem pemasaran tidak efisien (Ali, Situmorang, Murniati 2017).

Producer share (PS) digunakan untuk mengetahui bagian harga yang diterima produsen dari harga yang dibayarkan oleh konsumen akhir. Semakin tinggi pangsa produsen, maka kinerja pasar semakin baik dari sisi produsen. Pangsa produsen diperoleh dengan menggunakan rumus:

$\mathrm{PS}=\frac{\mathrm{PF}}{\mathrm{PR}} \times 100 \%$

Keterangan :

Ps = Bagian harga yang diterima petani (produsen)

Pf = Harga di tingkat petani (produsen)

$\operatorname{Pr}=$ Harga di tingkat konsumen

Elastisitas transmisi harga menggambarkan sejauh mana dampak dari perubahan harga suatu barang di suatu tempat/tingkatan terhadap perubahan harga barang di tempat lain. Transmisi harga diukur melalui regresi sederhana di antara dua harga pada dua tingkat pasar yang selanjutnya dihitung elastisitasnya (Hasyim 2012). Metode ini juga digunakan pada penelitian Pradika, Hasyim dan Soelaiman (2013) Secara matematis, elastisitas transmisi harga dapat dihitung dengan rumus sebagai berikut :

$\mathrm{Et}=\frac{\delta \mathrm{Pr}}{\delta \mathrm{Pf}} \times \frac{\mathrm{Pf}}{\operatorname{Pr}}$ $\mathrm{b}=\frac{\delta \mathrm{Pf}}{\delta \mathrm{Pr}} \mathrm{atau} \frac{\delta \operatorname{Pr}}{\delta \mathrm{Pf}}=\frac{1}{\mathrm{~b}}$

Maka

$$
\mathrm{ET}=\frac{1}{\mathrm{~b}} \times \frac{\mathrm{Pf}}{\mathrm{Pr}} .
$$

Kriteria pengukuran analisis transmisi harga adalah (Hasyim 2012) :

a) Jika $E_{t}=1$, pasar yang dihadapi oleh seluruh pelaku tataniaga adalah bersaing sempurna, dan sistem tataniaga yang terjadi sudah efisien.

b) Jika $E_{t}<1$, laju perubahan harga di tingkat konsumen lebih kecil dibanding dengan laju perubahan harga di tingkat produsen. Keadaan ini bermakna bahwa pemasaran yang berlaku belum efisien dan pasar yang dihadapi oleh pelaku tataniaga adalah bersaing tidak sempurna, yaitu terdapat kekuatan monopsoni atau oligopoli.

c) Jika $E_{t}>1$, laju perubahan harga di tingkat produsen. Pasar yang dihadapi oleh seluruh pelaku pasar adalah pelaku tidak sempurna, yaitu terdapat kekuatan monopoli dan oligopoli dalam sistem pemasaran tersebut serta sistem pemasaran yang berlaku belum efisien.

\section{HASIL DAN PEMBAHASAN}

Klanting memiliki beragam macam bentuk, rasa dan ukuran yang sangat bervariasi. Pada umumnya klanting ini memiliki dua warna yaitu merah dan putih, tekstur yang gurih serta renyah dan ukuran yang tidak terlalu besar dan memiliki masa kadaluarsa enam bulan. Produksi agroindustri klanting di Kecamatan Negeri Katon ini dikerjakan di rumah masing-masing produsen dengan luas bangunan berkisar $3 \times 7 \mathrm{~m}^{2}-3 \times 10 \mathrm{~m}^{2}$. Jumlah ratarata bahan baku ubi kayu yang digunakan dalam proses produksi adalah $1.356,25 \mathrm{~kg} / \mathrm{minggu}$ dan rata-rata hasil produksi adalah $157,5 \mathrm{~kg} /$ minggu. Kebutuhan akan bahan baku ubi kayu diperoleh dari luar daerah Kecamatan Negeri Katon, hal ini selaras dengan penelitian Sagala, Affandi dan Ibnu (2013) tentang kinerja usaha agroindustri kelanting di Desa Karang Anyar Kecamatan Gedongtataan Kabupaten Pesawaran yang menyatakan bahwa bahan baku tidak dapat dipenuhi oleh produsen klanting di Desa Karang Anyar, sehingga produsen harus memenuhi kebutuhan bahan baku dari luar wilayah Desa Karang Anyar.

Responden dalam penelitian ini adalah produsen agroindustri klanting di Kecamatan Negeri Katon sebanyak 32 produsen, lima pedagang pengumpul, 26 pedagang besar dan 113 pedagang pengecer yang ada di Kecamatan Negeri Katon maupun luar wilayah tersebut. Tingkat pendidikan produsen 
bervariasi, yaitu tingkat SD 43,75 persen, tingkat SMP 34,38 persen, dan tingkat SMA 21,86 persen. Produsen memiliki pengalaman usaha rata-rata empat tahun atau 68,75 persen. Sebaran usia produsen terbagi ke dalam empat kelompok, yaitu usia 35 - 40 sebanyak 15,63 persen, usia $41-46$ sebanyak 25,00 persen, usia 47 ke atas sebanyak 59,38 persen.

Agroindustri klanting di Kecamatan Negeri Katon sebagian besar merupakan usaha tetap yang dijalankan oleh produsen dan juga sebagai pekerjaan sampingan. Ketenagakerjaan dalam agroindustri klanting yang digunakan adalah tenaga kerja dalam keluarga dan luar keluarga. Hasil perhitungan jumlah rata-rata pendapatan produsen klanting di Kecamatan Negeri Katon adalah sebesar Rp2.018.932,67/bulan dengan nilai $\mathrm{R} / \mathrm{C}$ Ratio atas biaya tunai sebesar 1,38 dan $\mathrm{Rp} 1.649 .645,49 /$ bulan dengan nilai $\mathrm{R} / \mathrm{C}$ atas biaya total sebesar 1,29. Hasil perhitungan analisis pendapatan dapat dilihat pada Tabel 1 .

Fungsi pemasaran diperlukan dalam kegiatan pemasaran untuk memperlancar pendistribusian klanting dari setiap lembaga yang terlibat, terdiri dari fungsi pertukaran, fungsi fisik dan fungsi fasilitas. Pada fungsi pertukaran, hanya produsen yang tidak melakukan fungsi pembelian. Produsen tidak melakukan fungsi pengangkutan, karena para pedagang datang langsung untuk membeli produk. Fungsi standarisasi dan grading hanya dilakukan oleh pedagang besar. Penanggungan resiko hanya diterima oleh pedagang pengecer sebagai lembaga terakhir yang menjualkan klanting kepada konsumen.

Saluran pemasaran merupakan suatu jalur yang dilalui untuk memindahkan barang dari produsen kepada perantara dan akhirnya sampai ke konsumen. Proses pemasaran klanting di Desa Karang Rejo terdapat empat macam saluran pemasaran, antara lain :
(a) Produsen $\rightarrow$ Pedagang pengumpul $\rightarrow$ Pedagang Besar $\rightarrow$ Pedagang Pengecer $\rightarrow$ Konsumen
(b) Produsen $\rightarrow$ Pedagang Besar $\rightarrow$ Pedagang Pengecer $\rightarrow$ Konsumen
(c) Produsen $\rightarrow$ Pedagang Pengecer $\rightarrow$ Konsumen
(d) Produsen $\rightarrow$ Konsumen

Tabel 1. Total rata-rata penerimaan, biaya, dan R/C agroindustri klanting di Kecamatan Negeri Katon Kabupaten Pesawaran 2017

\begin{tabular}{|c|c|c|c|c|c|}
\hline Uraian & Satuan & Jumlah & Harga (Rp) & Nilai (Rp/Minggu) & Nilai (Rp/Bulan) \\
\hline \multicolumn{6}{|l|}{ Penerimaan } \\
\hline Produksi klanting & $\mathrm{Kg}$ & 157,50 & $11.593,13$ & $1.825 .917,19$ & 7.303.668,75 \\
\hline Total penerimaan & $\mathrm{Rp}$ & & & $1.825 .917,19$ & $7.303 .668,75$ \\
\hline \multicolumn{6}{|l|}{ Biaya produksi } \\
\hline \multicolumn{6}{|l|}{ I. Biaya tunai } \\
\hline Ubi kayu & $\mathrm{Kg}$ & $1.356,25$ & 661,25 & $896.820,31$ & $3.587 .281,25$ \\
\hline Garam & Pak & 2,21 & $7.083,33$ & $15.654,16$ & $62.616,64$ \\
\hline Minyak goring & $\mathrm{Kg}$ & 9,25 & $11.700,00$ & $108.199,41$ & $432.797,63$ \\
\hline Kayu bakar & kubik & 0,98 & $55.510,41$ & $54.400,20$ & $217.600,79$ \\
\hline Solar & Liter & 3,48 & $5.940,99$ & $20.674,65$ & $82.698,58$ \\
\hline Penyedap rasa & $\mathrm{Rp}$ & & & $8.812,50$ & $35.250,00$ \\
\hline Pewarna makanan & $\mathrm{Rp}$ & & & $3.500,00$ & $14.000,00$ \\
\hline Bawang putih & $\mathrm{Kg}$ & 1,97 & $34.088,53$ & $67.154,41$ & $268.617,65$ \\
\hline Plastik besar & $\mathrm{Kg}$ & 1,23 & $21.893,23$ & $26.928,67$ & $107.714,69$ \\
\hline Karung besar & Pcs & 2,01 & $2.500,00$ & $5.026,04$ & $20.104,17$ \\
\hline TK Luar keluarga & $\mathrm{HOK}$ & 7,45 & & $114.013,67$ & $456.054,69$ \\
\hline Total biaya tunai & $\mathrm{Rp}$ & & & $1.321 .184,02$ & $5.284 .736,08$ \\
\hline \multicolumn{6}{|l|}{ II. Biaya diperhitungkan } \\
\hline TK dalam keluarga & $\mathrm{HOK}$ & 2,49 & & $44.580,08$ & $178.320,31$ \\
\hline Penyusutan alat & $\mathrm{Rp}$ & & & $47.741,72$ & $190.966,87$ \\
\hline Total biaya diperhitungkan & $\mathrm{Rp}$ & & & $92.321,80$ & $369.287,18$ \\
\hline III. Total biaya & $\mathrm{Rp}$ & & & $1.413 .505,81$ & $5.654 .023,26$ \\
\hline \multicolumn{6}{|l|}{ Pendapatan } \\
\hline I. Pendapatan atas biaya tunai & $\mathrm{Rp}$ & & & $504.733,17$ & 2.018.932,67 \\
\hline $\begin{array}{l}\text { II. Pendapatan atas biaya total } \\
\text { R/C Ratio }\end{array}$ & $\mathrm{Rp}$ & & & $412.411,37$ & $1.649 .645,49$ \\
\hline I. R/C Ratio atas biaya tunai & & & & 1,38 & 1,38 \\
\hline II. R/C Ratio atas biaya total & & & & 1,29 & 1,29 \\
\hline
\end{tabular}


Salah satu indikator yang digunakan untuk menetukan efisiensi suatu sistem pemasaran adalah marjin pemasaran. Komponen biaya pemasaran klanting terdiri dari biaya transportasi, biaya tenaga kerja, biaya pengemasan dan biaya retribusi. Semakin banyak lembaga yang terlibat, maka semakin memperbesar marjin pemasaran.

Data pada Tabel 3 pada saluran 1, produsen menjual klanting kepada pedagang pengepul, pedagang besar, pedagang pengecer dan konsumen. Harga rata-rata klanting yang dijual produsen kepada pedagang pengepul sebesar Rp10.900/kg dan jumlah total biaya yang dikeluarkan produsen yang merupakan biaya tenaga kerja sebesar Rp1.071,19/kg. Biaya penjualan pedagang pengepul kepada pedagang besar sebesar Rp12.900/kg. Jumlah total biaya sebesar Rp202,12/kg yang meliputi biaya transportasi, biaya tenaga kerja dan biaya pengemasan. Biaya penjualan yang dilakukan oleh pedagang besar kepada pedagang pengecer adalah sebesar Rp14.375/kg dengan biaya total sebesar Rp516,37/kg. Biaya penjualan yang dilakukan oleh pedagang pengecer kepada konsumen sebesar Rp17.350/kg dengan biaya total sebesar Rp796,73/kg.

Data pada Tabel 4 saluran 2, produsen klanting menjual produknya kepada pedagang besar dengan harga rata-rata sebesar Rp10.956,5/kg. Pada saluran 2 ini, biaya yang dikeluarkan oleh produsen sebesar Rp1.114,79/kg yaitu untuk biaya tenaga kerja. Pedagang besar menjual produk klanting kepada pedagang pengecer dengan harga Rp12.784,73/kg. Jumlah total biaya yang dikeluarkan oleh pedagang besar sebesar $\mathrm{Rp} 1.237,08 / \mathrm{kg}$ dengan rincian biaya transportasi Rp375,86/kg, biaya tenaga kerja Rp729,47/kg dan biaya pengemasan Rp131,75/kg. Pedagang pengecer menjual kembali produk klanting kepada konsumen dengan harga rata-rata Rp16.736,11/kg. Total biaya yang dikeluarkan oleh pedagang pengecer sebesar Rp1.011,71, antara lain biaya pengemasan $\mathrm{Rp} 387,17 / \mathrm{kg}$, biaya transportasi $\mathrm{Rp} 219,82 / \mathrm{kg}$, biaya retribusi $\mathrm{Rp} 138,65 / \mathrm{kg}$ dan biaya tenaga kerja Rp266,09/kg.

Data pada Tabel 5 saluran 3, produsen menjual produk klanting kepada pedagang pengecer dengan biaya rata-rata sebesar Rp11.357,15/kg. Biaya yang dikeluarkan sebesar Rp2.207,01/kg, yaitu biaya tenaga kerja. Pada saluran 3, pedagang pengecer melakukan penjualan langsung kepada konsumen dengan harga Rp15.904,77/kg dengan jumlah total biaya $\mathrm{Rp} 802,47 / \mathrm{kg}$ dengan rincian biaya transportasi $\mathrm{Rp} 310,40 / \mathrm{kg}$, biaya pengemasan $\mathrm{Rp} 411,51 / \mathrm{kg}$ dan biaya retribusi Rp80,56/kg.

Tabel 2. Fungsi lembaga-lembaga pemasaran klanting di Kecamatan Negeri Katon 2017

\begin{tabular}{|c|c|c|c|c|}
\hline $\begin{array}{l}\text { Fungsi } \\
\text { Pemasaran }\end{array}$ & Prod. & $\begin{array}{c}\text { Pdg. } \\
\text { Pengumpul }\end{array}$ & $\begin{array}{l}\text { Pdg. } \\
\text { Besar }\end{array}$ & $\begin{array}{c}\text { Pdg. } \\
\text { Pengecer }\end{array}$ \\
\hline \multicolumn{5}{|l|}{ F. Pertukaran : } \\
\hline Pembelian & & $\sqrt{ }$ & $\sqrt{ }$ & $\sqrt{ }$ \\
\hline Penjualan & $\sqrt{ }$ & $\sqrt{ }$ & $\sqrt{ }$ & $\sqrt{ }$ \\
\hline \multicolumn{5}{|l|}{ F. Fisik: } \\
\hline Penyimpanan & $\sqrt{ }$ & $\sqrt{ }$ & $\sqrt{ }$ & $\sqrt{ }$ \\
\hline Pengolahan & $\sqrt{ }$ & & $\sqrt{ }$ & $\sqrt{ }$ \\
\hline Pengangkutan & & $\sqrt{ }$ & $\sqrt{ }$ & $\sqrt{ }$ \\
\hline \multicolumn{5}{|l|}{ F. Fasilitas: } \\
\hline \multicolumn{5}{|l|}{ Standarisasi } \\
\hline Penanggungan & & & & \\
\hline Resiko & & & & $\sqrt{ }$ \\
\hline Pembiayaan & $\sqrt{ }$ & & & \\
\hline Informasi & & & & \\
\hline Pasar & $\sqrt{ }$ & $\sqrt{ }$ & $\sqrt{ }$ & $\sqrt{ }$ \\
\hline
\end{tabular}

Tabel 3. Sebaran harga rata-rata dan marjin pemasaran klanting saluran 1

\begin{tabular}{|c|c|c|c|}
\hline No & Uraian & $\mathrm{Rp} / \mathrm{Kg}$ & $\%$ \\
\hline \multirow[t]{3}{*}{1.} & Harga jual produsen & $10.900,00$ & 62,79 \\
\hline & Biaya & & \\
\hline & Tenaga kerja & $1.071,19$ & 6,18 \\
\hline \multirow[t]{10}{*}{2.} & Pengepul & & \\
\hline & a. Harga beli & $10.900,00$ & 62,83 \\
\hline & b.Margin pemasaran & $2.000,00$ & 11,53 \\
\hline & c.Biaya & 202,12 & 1,17 \\
\hline & Transportasi & 202,12 & 1,17 \\
\hline & Tenaga kerja & & \\
\hline & Pengemasan & & \\
\hline & d.Margin keuntungan & $1.797,88$ & 10,37 \\
\hline & e.Rasio profit margin & 8,90 & 0,06 \\
\hline & f Harga jual & $12.900,00$ & 74,36 \\
\hline \multirow[t]{10}{*}{3.} & Pedagang besar & & \\
\hline & a. Harga beli & $12.900,00$ & 74,36 \\
\hline & b. Margin pemasaran & $1.475,00$ & 8,51 \\
\hline & c. Biaya & 516,37 & 2,98 \\
\hline & Tranportasi & 139,59 & 0,81 \\
\hline & Tenaga kerja & 252,38 & 1,46 \\
\hline & Pengemasan & 124,41 & 0,72 \\
\hline & d. Margin keuntungan & 958,63 & 5,53 \\
\hline & e. Rasio profit margin & 1,86 & 0,02 \\
\hline & f. Harga jual & $14.375,00$ & 82,86 \\
\hline \multirow[t]{11}{*}{4.} & Pedagang pengecer & & \\
\hline & a. Harga beli & $14.375,00$ & 82,86 \\
\hline & b. Margin pemasaran & $2.975,00$ & 17,15 \\
\hline & c. Biaya & 796,73 & 4,60 \\
\hline & Transportasi & 191,48 & 1,11 \\
\hline & Tenaga kerja & 252,38 & 1,46 \\
\hline & Pengemasan & 257,38 & 1,49 \\
\hline & Retribusi & 95,50 & 0,56 \\
\hline & d. Margin keuntungan & $2.178,28$ & 12,56 \\
\hline & e. Rasio profit margin & 2,74 & 0,02 \\
\hline & f. Harga jual & $17.350,00$ & 100,00 \\
\hline 5 & Konsumen & $17.350,00$ & 100,00 \\
\hline
\end{tabular}


Tabel 4. Sebaran harga rata-rata dan marjin pemasaran klanting saluran 2

\begin{tabular}{clrr}
\hline No & \multicolumn{1}{c}{ Uraian } & $\mathrm{Rp} / \mathrm{Kg}$ & \multicolumn{1}{c}{$\%$} \\
\hline 1 & Harga jual produsen & $10.956,50$ & 58,81 \\
\hline & Biaya & & \\
& Tenaga kerja & $1.114,79$ & 6,67 \\
\hline 2 & Pedagang besar & & \\
\hline & a. Harga beli & $10.956,50$ & 65,47 \\
& b. Margin pemasaran & $1.828,22$ & 10,93 \\
& c. Biaya & $1.237,08$ & 7,40 \\
& Tranportasi & 375,86 & 2,25 \\
& Tenaga kerja & 729,47 & 4,36 \\
d. Pengemasan & 131,75 & 0,79 \\
d. Margin keuntungan & 591,15 & 3,54 \\
e. Rasio profit margin & 0,48 & 0,01 \\
f. Harga jual & $12.784,73$ & 76,40 \\
\hline 3 & Pedagang pengecer & & \\
\hline & a. Harga beli & $12.784,73$ & 76,40 \\
b. Margin pemasaran & $3.951,39$ & 23,61 \\
& c. Biaya & $1.011,71$ & 6,05 \\
& Transportasi & 219,82 & 1,32 \\
& Tenaga kerja & 266,09 & 1,59 \\
& Pengemasan & 387,17 & 2,32 \\
& Retribusi & 138,65 & 0,83 \\
& a. Margin keuntungan & $2.939,69$ & 17,57 \\
& b. Rasio profit margin & 2,91 & 0,02 \\
c. Harga jual & $16.736,11$ & 100,00 \\
\hline 4 & Konsumen & $16.736,11$ & 100,00 \\
\hline & & &
\end{tabular}

Tabel 5. Sebaran harga rata-rata dan marjin pemasaran klanting saluran 3

\begin{tabular}{llrr}
\hline No & Uraian & $\mathrm{Rp} / \mathrm{Kg}$ & \multicolumn{1}{c}{$\%$} \\
\hline 1 & Harga jual produsen & $11.357,15$ & 71,32 \\
\hline & Biaya Tenaga kerja & $2.207,01$ & 13,88 \\
\hline 2 & Pedagang pengecer & & \\
\hline \multirow{2}{*}{ a. Harga beli } & $11.357,15$ & 71,41 \\
& b. Margin pemasaran & $4.547,62$ & 28,60 \\
& c. Biaya & 802,47 & 5,05 \\
& Tranportasi & 310,40 & 1,96 \\
& Tenaga kerja & & \\
& Pengemasan & 411,51 & 2,59 \\
& Retribusi & 80,56 & 0,51 \\
& d. Margin keuntungan & $3.745,16$ & 23,55 \\
& e. Rasio profit margin & 4,67 & 0,03 \\
& f. Harga jual & $15.904,77$ & 100,00 \\
\hline 3 & Konsumen & $15.904,77$ & 100,00 \\
\hline
\end{tabular}

Data Tabel 6 pada saluran 4, saluran ini memiliki rantai pemasaran yang lebih pendek dibandingkan dengan saluran pemasaran lainnya. Produsen melakukan penjualan klanting langsung kepada konsumen dengan harga rata-rata sebesar $\mathrm{Rp} 12.823,53 / \mathrm{kg}$. Biaya yang dikeluarkan sebesar Rp619,61/kg, yaitu biaya pengemasan. Dari empat macam saluran pemasaran yang ada, saluran empat merupakan saluran yang paling efisien dibandingkan saluran lainnya karena memiliki nilai pangsa produsen sebesar 99,97 persen.

Indikator lain untuk menentukan efisiensi suatu pemasaran adalah menghitung rasio keuntungan terhadap biaya. Berdasarkan Tabel 7, saluran pemasaran 1 memiliki perbedaan nilai RPM yang relatif tidak menyebar merata pada tiap lembaga pemasarannya. Pedagang pengepul memiliki nilai selisih yang besar yaitu 8,90 dibandingkan dengan nilai pedagang besar sebesar 1,86 dan pedagang pengecer sebesar 2,74. Hal ini selaras dengan penelitian Ramadinata, Hasyim dan Situmorang (2014) Perbedaan selisih nilai RPM juga terdapat pada saluran lainnya yang menggambarkan bahwa setiap lembaga saluran pemasaran mengambil keuntungan yang sangat besar.

Apabila Producer Share (PS) semakin tinggi, maka kinerja pasar semakin baik dari sisi produsen. Pada saluran pemasaran 2, pangsa produsen (PS) yang diterima oleh produsen relatif lebih kecil dibandingkan dengan saluran pemasaran lainnya dengan nilai persentase sebesar 58,80 persen dikarenakan perbedaan nilai harga yang diterima produsen dengan konsumen akhir relatif lebih tinggi dibandingkan dengan saluran pemasaran lainnya. Pangsa produsen (PS) dengan nilai persentase terbesar terdapat pada saluran 4 yaitu 99,97 persen, dimana pada saluran ini produsen langsung memasarkan produk klanting kepada konsumen. Sebaran persentase pangsa produsen dapat dilihat pada Tabel 8 .

Tabel 6. Sebaran harga-harga dan margin pemasaran klanting saluran 4

\begin{tabular}{clcr}
\hline No & \multicolumn{1}{c}{ Uraian } & $\mathrm{Rp} / \mathrm{Kg}$ & $\%$ \\
\hline 1. & $\begin{array}{l}\text { Harga jual } \\
\text { produsen }\end{array}$ & $12.823,53$ & 99,97 \\
& $\begin{array}{l}\text { Biaya } \\
\text { Pengemasan }\end{array}$ & 619,61 & 4,84 \\
\hline 2. & Konsumen & $12.823,53$ & 100,00 \\
\hline
\end{tabular}

Tabel 7. Sebaran rasio keuntungan terhadap biaya (RPM) masing-masing saluran pemasaran klanting di Kecamatan Negeri Katon, 2017

\begin{tabular}{cccc}
\hline \multirow{2}{*}{ Saluran } & \multicolumn{3}{c}{ Lembaga pemasaran } \\
\cline { 2 - 4 } & $\mathrm{PP}$ & $\mathrm{PB}$ & $\mathrm{Pp}$ \\
\hline 1. & 8,90 & 1,86 & 2,74 \\
2. & & 0,48 & 2,91 \\
3. & & & 4,67 \\
\hline
\end{tabular}


Tabel 8. Sebaran pangsa produsen klanting pada setiap saluran pemasarannya di Kecamatan Negeri Katon, 2017

\begin{tabular}{ccc}
\hline No & $\begin{array}{c}\text { Saluran } \\
\text { pemasaran }\end{array}$ & $\begin{array}{c}\text { Pangsa } \\
\text { Produsen }(\%)\end{array}$ \\
\hline 1. & 1 & 62,79 \\
2. & 2 & 58,81 \\
3. & 3 & 71,32 \\
4. & 4 & 99,97 \\
\hline & Rata-Rata & 73,22 \\
\hline
\end{tabular}

Tabel 9. Hasil analisis regresi fungsi marjin klanting di Desa Karang Rejo Kecamatan Negeri Katon 2017

\begin{tabular}{lll}
\hline Variabel & Koef. Regresi & Sig. \\
\hline Konstanta & $-8217,219$ & 0,001 \\
$\begin{array}{l}\text { Harga ditingkat } \\
\text { konsumen }\end{array}$ & 1,159 & 0 \\
\hline F-hitung & 115,142 & \\
$\mathrm{R}^{2}$ adjusted & 0,898 & 0 \\
$\mathrm{R}^{2}$ & 0,906 & \\
\hline
\end{tabular}

Elastisitas transmisi harga merupakan analisis untuk mengetahui besarnya dampak perubahan harga di tingkat produsen terhadap perubahan harga di tingkat konsumen. Hasil perhitungan ratarata $\mathrm{Pf}=11.629,87$ dan rata-rata nilai $\mathrm{Pr}=$ 17.126,62. Dari hasil regresi harga klanting tersebut diperoleh model fungsi marjin sebagai berikut :

$$
\mathrm{Pf}=-8217,219+1,159 \mathrm{Pr}
$$

Hasil analisis uji statistik menunjukkan nilai koefisien determinasi $\left(\mathrm{R}^{2}\right)$ adalah 0,906 yang berarti bahwa variabel harga di tingkat konsumen berpengaruh nyata terhadap harga ditingkat produsen pada taraf kepercayaan sebesar 90,6 persen. Model fungsi marjin menunjukkan bahwa koefisien harga ditingkat konsumen sebesar 1,159, sehingga secara matematis elastisitas transmisi harga dapat dituliskan sebagai berikut :

$\mathrm{ET}=\frac{1}{1,159} \times \frac{11.629,87}{17.126,62}$

$$
\mathrm{ET}=0,586
$$

Berdasarkan hasil uji statistik dan perhitungan, dapat kita ketahui bahwa diperoleh nilai elastisitas transmisi harga sebesar 1,7067 yang menunjukkan bahwa laju perubahan harga ditingkat konsumen atau pedagang pengecer sebesar 1 persen akan ditransmisikan terhadap perubahan harga ditingkat produsen sebesar 1,7067 persen.
Hal ini selaras dengan penelitian Prayitno, Hasyim dan Situmorang (2013), bahwa nilai elastisitas transmisi harga lebih besar dari satu berarti laju perubahan harga di tingkat konsumen lebih besar dibandingkan dengan laju perubahan di tingkat produsen. Keadaan ini berarti bahwa pasar yang dihadapi pelaku tataniaga adalah pasar bersaing tidak sempurna dengan kata lain sistem pemasaran yang berlangsung belum efisien.

\section{KESIMPULAN}

Pendapatan produsen agroindustri klanting di Kecamatan Negeri Katon menguntungkan dengan atas biaya total dan biaya tunai. Pemasaran klanting pada agroindustri klanting di Kecamatan Negeri Katon menggunakan empat saluran pemasaran. Berdasarkan marjin pemasaran, Ratio Profit Margin (RPM) dan elastisitas transmisi harga (Et) menunjukkan bahwa pasar yang terjadi adalah tidak bersaing sempurna dan belum efisien.

\section{DAFTAR PUSTAKA}

Ali MF, Situmorang S, dan Murniati K. 2017. Analisis efisiensi pemasaran kubis di Kecamatan Gisting Kabupaten Tanggamus. JIIA,5(3):258-266. http://jurnal.fp.unila .ac. id/index.php/JIA/articleview/1638/1464.[02 Maret 2018].

Badan Pusat Statistik Kabupaten Pesawaran. 2015. Pelaku Industri Makanan Kerajinan Rakyat. BPS Gedong Tataan. Kabupaten Pesawaran.

Badan Pusat Statistik Provinsi Lampung. 2015. Produk Domestik Regional Bruto Provinsi Lampung Menurut Lapangan Usaha 20122015. BPS Provinsi Lampung. Bandar Lampung.

Kantor Desa Karang Rejo. 2017. Profil Desa Karang Rejo. Kantor Kelurahan. Gedong Tataan

Hasyim AI. 2012. Tataniaga Pertanian. Universitas Lampung. Bandar Lampung

Pradika A, Hasyim AI, dan Soelaiman A. 2013. Analisis efisiensi pemasaran ubi jalar di Kabupaten Lampung Tengah. JIIA, 1(1) : 25 -35. http://jurnal.fp.Unila.ac.id/index.php/JIA /article/view/128/132. [20 April 2016].

Prayitno AB, Hasyim AI, dan Situmorang S. 2013. Efisiensi pemasaran cabai merah di Kecamatan Adiluwih Kabupaten Pringsewu Provinsi Lampung. JIIA, 1.(1): 53 - 59. http://jurnal.fp.unila.ac.id/index.php/JIA/articl e/view/131/135. [21 April 2016]. 
Ramadinata F, Hasyim AI, dan Situmorang S. 2014. Efisiensi pemasaran produk duku Lampung melalui pendekatan serba fungsi di Kabupaten Lampung Selatan. JIIA, 2 (3) : 223-231. http://jurnal.fp.unila.ac.id/index.php /JIA/article/vi ew/804/734. [02 Maret 2018].

Rahim ABD dan Hastuti DRD. 2008. Ekonometrika Pertanian (Pengantar Teori dan Kasus). Penebar Swadaya. Jakarta.
Sagala IC, Affandi MI, dan Ibnu M. 2013. Kinerja usaha agroindustri klanting di Desa Karang Anyar Kecamatan Gedong Tataan Kabupaten Pesawaran. JIIA. 1 (1). : 60 - 65. http:// jurnal.fp.unila.ac.id/index.php/JIA/article/vie w/132/136. [24 Juli 2018].

Sarwono J. 2006. Metode Penelitian Kuantitatif dan Kualitatif. Graha Ilmu. Yogyakarta. 